\title{
Evaluation of The Social Care Program of Regional Leadership Council Partai Amanat Nasional (PAN) of Batu City in Spraying Disinfectants
}

\author{
Imam Wahyu Utomo \\ Universitas Muhammadiyah Malang \\ e-mail : imamwahyu1612@gmail.com \\ Puteri Nur Anisa Larasati \\ Universitas Muhammadiyah Malang \\ e-mail : larasatiputri669@yahoo.com \\ Fernandha Wahyu $S$ \\ Universitas Muhammadiyah Malang \\ e-mail : fernandawahyu112@gmail.com \\ Alung Vinedal \\ Universitas Muhammadiyah Malang \\ e-mail : alungvinedal340@gmail.com
}

\begin{abstract}
This study aims to produce an Evaluation of Care Program in spraying Disinfectant to Prevent the Spread of Corona Virus by the Regional Leadership Council (DPD) Partai Amanat Nasional (PAN) of the Batu City. The method used in this study is a qualitative research method. Data collection techniques by observation, interview and documentation. The model used is non participatory evaluation research. The results of this study are programs run by the Regional Representative Council (DPD) of the partai Amanat Nasional (PAN) of Batu City in the form of a social care program for spraying disinfectants to prevent the spread of the corona virus through inanimate objects in the Batu City area. because of their initial goal of doing this program for the hurricane and foundations in the Batu City area, when residents heard that spraying was being done by the Regional Representative Council (DPD) of Partai Amanat Nasional (PAN) of Batu City, enthusiastic attitudes of the community immediately arose to ask for spraying in the village they were so Regional Representative Council (DPD) Partai amanat Nasional (PAN) of Batu city experienced constraints in the volunteer workforce.
\end{abstract}

Keywords: Evaluation program, Social care, Disinfectant.

\section{INTRODUCTION}

Coronavirus is a group of viruses from the Orthocronavirinae subfamily in the Coronaviridae family and the order Nidovirales. This group of viruses can cause disease in birds and mammals, including humans. In humans, the coronavirus causes generally mild respiratory infections, such as colds, although some forms of the disease include; SARS, MERS and COVID-19 are even more deadly. In current conditions, the corona virus is not an epidemic that can be ignored. When viewed from the symptoms, ordinary people would think that it was only limited to ordinary influenza, but for medical analysis this virus is quite dangerous and deadly. 
Currently the corona virus problem is a social problem among people around the world, where the corona virus has occurred in early December 2019 starting from China, the corona virus has spread throughout the world including Indonesia, the number of cases suffering from the virus has reached a number high enough that the government and society have tried to anticipate so as not to be infected by the corona virus, the government has made policies for the community so the people do physical distancing and also continue to limit their activities outside the home (stay at home). The problem with the corona virus has resulted in changes in people's lives and has also had a considerable impact, namely in the economic and education sectors. As a result, many companies or factories have experienced a decrease in income so that they cannot pay their employees' wages and many employees have been laid off, besides that in the education sector throughout Indonesia they are closed and carry out school activities or study at home only or with an online system, from that the system of teaching is also ineffective.

In these conditions, there are some care groups which have emerged working to help anticipate or prevent the spread of the corona virus. This group makes an excellent contribution to the prevention of the corona virus, this group is part of the Regional Leadership Council (DPD) of the Partai Amanat Nasional (PAN) of Batu City where they create a social care program, namely spraying disinfectant liquid in the Batu City area, including residential areas. residents, places of worship, school areas, orphanages, and also in the Batu City police area, which aims to prevent the spread of the corona virus.

The social care program planned by the Regional Leadership Council (DPD) of Partai Amanat Nasional (PAN) of Batu City in spraying disinfectant liquid to prevent the spread of the corona virus, disinfectant is a selective material used to destroy diseases caused by organisms originating from bacteria, viruses, and amoeba. The content contained in disinfectant fluids is chlorine and alcohol, chlorine was chosen as a disinfectant in wastewater treatment because according to Said (2007), chlorine in chlorine, especially $\mathrm{HOCl}$, is generally very effective in killing pathogens and indicator bacteria, while alcohol is also chosen as a disinfectant liquid. in the alcohol, there is a triclosan content of $0.05 \%$, chamomile extract $0.05 \%$ which is able to kill bacteria and viruses. (Setiawan, Sibarani, and Sup]in 2013)

In this study, we researchers want to see and examine how the effectiveness of the Regional Leadership Council (DPD) Partai Amanat Nasional (PAN) of Batu City in the social care program in spraying disinfectants to prevent the spread of the corona virus. In this case the successful implementation of the disinfectant spraying program can be seen from the impact as a result of evaluating the implementation of a program. As we know, one of the weaknesses of program activities is weakness in evaluation. Even though the activities have been successfully organized, it is easy to discontinue them. Even though the disinfectant spraying program cannot be done once or twice, because it requires sustainability during the corona virus pandemic, this research will contribute to encouraging the sustainability of the social care program carried out by the Regional Leadership Council (DPD) of the Partai Amanat Nasional (PAN) of Batu City in its disinfectant spray.

From the research, we took samples or case studies at the Regional Leadership Council (DPD) of the Partai Amanat Nasional (PAN) of Batu City in an effort to obtain 
objective data, the location we made the object of research was Jalan Samadi No.36, Pesanggrahan, Kec. Batu, Batu City. In our observations, we focused on how the programs compiled by the Regional Leadership Council (DPD) Partai Amanat Nasional (PAN) of the Batu City, how were the parties in the Regional Leadership Council (DPD) Partai Amanat Nasional of Batu city in implementing social care programs, how is the public responds to social care programs, namely spraying disinfectants formulated by the Regional Leadership Council (DPD) of the Partai Amanat Nasional (PAN) of Batu City.

The formulation of the problem in this research is how the effectiveness of the social care program of the Regional Leadership Council (DPD) Partai Amanat Nasional (PAN) of the Batu City in spraying disinfectants to prevent the spread of the corona virus? What is the form of evaluation of the existence of the Regional Leadership Council (DPD) Partai Amanat Nasional (PAN) for social care program of Batu City in spraying disinfectants to prevent the spread of the corona virus?

The purpose of this study is to assess the advantages and disadvantages of social care programs in spraying disinfectants to prevent the spread of the corona virus formulated by the Regional Leadership Council (DPD) Partai Amanat Nasional (PAN) of the Batu City to the community, so that our group can evaluate the programs that have been made and to find out the form of evaluation of the existence of a social care program in spraying disinfectants to prevent the spread of the corona virus formulated by the Regional Leadership Council (DPD) Partai Amanat Nasional (PAN) of Batu City to the community, so our group can find out whether the program has been made by the Leadership Council Regional (DPD) Partai Amanat Nasional (PAN) of Batu City succeeded or not.

\section{RESEARCH METHODS}

This study uses descriptive qualitative research methods using an evaluation model, namely non-participatory. Another term is program evaluation. Program evaluation, namely the application of systematic methods to deal with problems related to program implementation and results. Considering that this activity is a series, the program evaluation carried out is a one-shot program (Newcomer, Kathryn, E et al, 2015), considering that the program has been completed and researchers are still considering whether to continue it or not. Thus, it can be said that the program evaluation here is part of an ongoing assessment system.

Researchers took the research location at the office of the Regional Leadership Council (DPD) of Partai Amanat Nasional (PAN) in Batu City, namely Jl. Samadi No.36, Pesanggrahan, Kec. Batu, Batu city. When the research was conducted from May to June. The subjects of this study were members of the Regional Leadership Council (DPD) of Partai Amanat Nasional (PAN) of Batu City. The research subjects using a snowball sampling system. Snowball sampling is like a snowball that keeps rolling and becomes very large. Snowball Sampling is a technique of sampling data sources, which initially the number is a little bit and will eventually become large (Sugiono, 2012: 54). Primary data collection was carried out in 2 ways, namely using observation techniques and in-depth interviews with members of the Regional Leadership Council (DPD) of the Partai Amanat Nasional (PAN) of Batu City. Analysis of the data used to explain the above problems, using descriptive data analysis 
techniques starting from reviewing the data previously obtained from informants in the form of raw data. The raw data is then processed systematically.

\section{FINDING AND DISCUSSION}

The author wants to discuss about research that has been researched, namely the social care program formulated by the Regional Leadership Council (DPD) Partai Amanat Nasional (PAN) of the Batu City in spraying disinfectants to prevent the spread of the corona virus.

\section{The effectiveness of the social care program of the Regional Leadership Council (DPD) Partai Amanat Nasional (PAN) of Batu City in spraying disinfectantas to prevent the corona virus}

Various things have been done to reduce the spread of the corona virus, one of them is by making ideas related to sterility, namely the use of disinfectants. In disinfectants, there are several ingredients, such as chlorine and alcohol, which can kill bacteria. Usually it sprays on the surface of objects, such as door handles, tables, to the surface of the highway. At the time of the corona virus pandemic, disinfectants became a mainstay because they were considered capable of sterilizing various areas. However, according to the journal released by The Lancer Infectious Diseases recently, there are many activities of spraying disinfection in public facilities and in people's homes to prevent the spread of the Corona virus. The country must deal with the current epidemic by cultivating efforts to prevent the spread of the virus, one of which is by spraying disinfectants, even though using the simplest tools. (Komala 2014)

The Regional Representative Council (DPD) Partai Amanat Nasional (PAN) of Batu City also carried out disinfectant spraying activities as a social concern for the health of the Batu community which was carried out for 3 months starting in early March since Indonesia was first exposed to the corona virus. The target of the Regional Representative Council (DPD) Partai Amanat Nasional (PAN) of Batu City in spraying disinfectants to prevent the corona virus is a place that has not been touched by the hands of the government at all, the government only carries out these activities only in Batu City, so the Regional Representative Council (DPD) ) Partai Amanat Nasional (PAN) of Batu City carried out spraying of disinfectants in three villages located in Batu City including Bumiaji sub-district, Batu sub-district, Junrejo sub-district, prayer rooms, schools, orphanage foundations, and Islamic boarding schools.

Activities carried out by the Regional Representative Council (DPD) of Partai Amanat Nasional (PAN) of Batu City can be considered effective because the spraying is carried out using a disinfectant that has been certified to kill microbes or viruses in inanimate objects and they use direct disinfectant liquid take from Jakarta and the liquid is authentic so that it can be measured as safe for humans.

The community was also enthusiastic helping to spray the program carried out by the PAN party, and many people in Batu submitted a request to the Regional Representative Council (DPD) of Partai Amanat Nasional (PAN) of Batu City to spray their village, because the community knew that the liquid was being sprayed. It has good quality so that the effect that occurs when exposed to the body is not too dangerous, this program can be said to be effective because the Regional Representative Council (DPD) of Partai Amanat Nasional (PAN) of Batu City does it with procedures that have been implemented by the government and does not violate the rules are made. 
In addition to the disinfectant spraying program, the Regional Representative Council (DPD) of Partai Amanat Nasional (PAN) of Batu City has also created a program to distribute hands-initizers, social assistance, distribution of vegetables, free medical treatment, and also provide outreach for residents to wash their hands with soap (minimum 20 seconds), take a shower and change clothes after doing activities from outside or from a highly infected place, and apply physical distancing (at least 1 meter).

\section{Evaluation of the existence of a social care program for the Regional Representative Council (DPD) Partai Amanat Nasional (PAN) in Batu city in spraying desinfectants to prevent the spread of the corona virus}

Spraying disinfectants activity carried out by the Regional Representative Council (DPD) of Partai Amanat Nasional (PAN) of Batu City has been running for 3 months since the beginning of March, from the data our group found there were a series of activities for seven days in spraying disinfectants carried out by the Regional Representative Council (DPD) Partai Amanat Nasional (PAN) of Batu City, activities on the first day of the chairman of the Regional Representative Council (DPD) Partai Amanat Nasional (PAN) of Batu City and all cadres can carry out spraying disinfectants activities in all Islamic boarding schools in Batu City. On the first day of Saturday, March 28, 2020 we can spray around 8 points starting from the village area of Tulungrejo to the village of Beji. On the second day, the week of 29 March 2020, spraying of disinfectants was carried out in several Islamic boarding schools which had not been carried out the previous day due to weather and time. Apart from several Islamic boarding schools, the Chairman the Regional Representative Council (DPD) Partai Amanat Nasional (PAN) of Batu City along with his cadres also sprayed several villages, one of them was Pesanggrahan Village of Batu city where previously there were residents affected by the corona virus, on the day the three Heads of the Regional Representative Council (DPD) Partai Amanat Nasional (PAN) of Batu City along with their cadres sprayed disinfectants, including in Bulukerto Village, Buludendeng Hamlet and Gintung. In addition to spraying disinfectant, the Chairman of the Regional Representative Council (DPD) Partai Amanat Nasional (PAN) of Batu City along with his cadres also distributed Hand Sanitizers to the surrounding community, on the fourth day the Chair of the Regional Representative Council (DPD) Partai Amanat Nasional (PAN) of Batu City spraying disinfectants which is one of the efforts of the Regional Representative Council (DPD) Partai Amanat Nasional (PAN) of Batu City in preventing the Corona virus after all Ponpes and Orphanage Foundations, continued in several areas in Batu City, namely Jl. Diran to Jl. Imam Bonjol, Pesanggrahan Batu, and several places of worship in Batu City. On the fifth day of spraying disinfectants in Junrero Subdistrict, Punten Bumiaji Village, and Tulungrejo Bumiaji Village on April 2 , 2020. The more responsiveness of the community, so many requests from local people to spray disinfectants from social care programs held by the Regional Representative Council (DPD) Partai Amanat Nasional (PAN) of Batu City in their villages. On April 3, 2020, spraying disinfectants was continued in the Batu City Pesanggrahan area, especially in boarding houses and housing located at Gg.1, Jl. Samadi, Pesanggrahan Kota Batu. In addition, the Batu City Police the Regional Representative Council (DPD) Partai Amanat Nasional (PAN) of Batu City of Batu City to carry out spraying at its office. And also part of Tonggolari Hamlet, Sidomulyo. 
The evaluation that can provide from our research is that the spraying disinfectants activity program has been running well and has received enthusiasm from many citizens because the Regional Representative Council (DPD) Partai Amanat Nasional (PAN) of Batu City spraying disinfectants is in a bad area. The government is completely touched by the spraying of disinfectant liquid that has been tested and verified so that the public knows that the content in the disinfectant liquid is safe for the community. From the disinfectant spraying program carried out by the Regional Representative Council (DPD) Partai Amanat Nasional (PAN) of Batu City has obstacles, namely from a lack of labor, so that our group has suggestions for disinfectant spraying program activities carried out by the Regional Representative Council (DPD) Partai Amanat Nasional (PAN) of Batu City, namely by opening registration for volunteers or cooperating with agencies so that they have more personnel so that they can help more broadly in the Batu City area in disinfectant spraying program activities.

\section{Quotes and References}

A review of the relevant literature that underlies the idea in this study are explaining the importance of social care programs for spraying disinfectants to prevent the corona virus. The importance of the disinfectant spraying program to prevent the corona virus is considering that the corona virus has spread in the country of Indonesia and the Indonesian people must prevent the transmission of the corona virus starting from spraying disinfectants, for this the social care program in spraying disinfectants is a very important contribution.

Social care in general is treating people well, being tolerant, able to work together, willing to be involved with society, love and peace in dealing with problems (Hariyanto, 2013). provide assistance to other people and communities in need (Kadek Alit Arsani 2013)

The advantage of social care is social care in line with the values of altruism. Altruism is a desire to help others without prioritizing one's own interests. Altruism is shown by individuals because basically humans are creatures who like to help (altruist). A behavior is said to be altruistic depending on the goals of the helper, and also from a social care attitude it can foster a culture of mutual cooperation (Sarwono, 2002)

The effort of social care activities is that individuals who are bound to each other are expected to foster willingness to help others anytime, anywhere and without expecting anything in return from the person or family they help. Willingness to help because individuals as social beings always need help from others and cannot live separately from others (Syaribulan and Akhir 2017)

Some of the keys to the success of social care activities are mutual understanding and mutual assistance between individuals and other individuals, there is no difference between one another, forming a team, working with stakeholders, and also working together (Anon 2016).

The first relevant finding is from Reza Rinaldy, Soni A. Nulhaqim and Arie Surya Gutama in 2017 with the title Community Development Process in the Climate Village Program in Cupang Village, Gempol District, Cirebon Regency (Case Study of the Waste Bank Program in the Climate Village Program) This research aims to describe the process community development which consists of stages of engagement, assessment, program planning, formulation of action plans, implementation, evaluation 
and results of changes, and stages of termination. The Community Development process carried out in Cupang Village through the waste bank program from PT Indocement's CSR activities. The research method used is descriptive type with a qualitative approach, and case study research techniques. Data collection techniques include indepth interviews, non-participatory observation, literature study and documentation study. The results of this study indicate the community development process in 7 stages carried out, only 5 stages have been running properly, namely the stages of engagement, assessment, program planning, implementation, and termination. The evaluation stage has not been carried out thoroughly and continuously. Other findings in this study indicate constraints on product marketing and organizational management, especially on human resources (HR) in carrying out activities. Thus, the researcher suggests that a comprehensive evaluation should be carried out on the capacity building of the waste management group in the form of an "Organizational Management" Workhshop activity to increase knowledge and understanding related to organizational management among members of the waste management group. (RINALDY, NULHAQIM, and GUTAMA 2017).

The second relevant finding is from Josias Jefry Suitela in 2017 entitled Social Assistance in Capacity Building for Joint Business Groups in Bandung. This research aims to produce the right model for social assistance in developing the capacity of KUBE. The method used in this research is a qualitative research method with the type of action research (action research). Action research is a research that is used to make changes to individuals, groups and communities in fulfilling needs or solving problems they face. The research site was conducted in Cibeunying Village, Cimenyan District, Bandung Regency. The social assistance model in developing group capacity is carried out through comparative studies, training / outreach, as well as increasing cooperation with related parties and social services. The social assistance that has been implemented has resulted in a model that can be applied to sub-urban communities with the same characteristics. However, this study cannot be generalized in general. Assistance is applied to obtain information on the description of KUBE social assistance to perfect the initial design at the time of social assistance in KUBE capacity development, the result of the implementation of the initial social assistance design in KUBE capacity development and the final design. The program design to be formulated comes from the results of the implementation of the follow-up plan for the capacity building program that has carried out four activities through social assistance. social assistance in developing the capacity of KUBE has been proven to have increased the capacity of administrators and members in managing KUBE Maju Sejahtera in Cibeunying Village. financial transparency. (Josias, 2017).

The third relevant finding is from Evi Rahmawati and Bagus Kisworo in 2017 entitled The Role of Facilitators in Empowering the Poor through the Family Hope Program. This research aims to describe the role of companions, inhibiting and supporting factors in mentoring the Family Hope Program in Central Semarang District. This study uses a qualitative approach, a companion as the research subject, Interview, observation and documentation as data collection techniques. The validity of the data used triangulation of sources, methods and theories. The data analysis used an interactive cycle. The results showed that the assistant has four skill roles, namely the role of facilitative, educator, community representative, and technical. The internal factor that became the obstacle was the difficulty of the participants to collect data files, 
and adapting to the new environment of the companion took a long time. The external factors that become obstacles are sudden information from the center, the distance the companion travels to the mentor's place is quite far and the location of the mentor's place is in a narrow alley. The supporting factor is the enthusiasm of the beneficiaries and adequate facilities. (Rahmawati and Kisworo 2017).

More specifically, of the three findings, which have discussed about social care programs regarding the economy, a lot has been done, but research on social care activities based on spraying disinfectants to maintain the health of rural communities against the corona virus in the Regional Representative Council (DPD) Partai Amanat Nasional (PAN) of Batu City has not yet conducted this research so our group is interested in conducting this research and at the same time evaluating the social care program of the Regional Representative Council (DPD) Partai Amanat Nasional (PAN) of Batu City

\section{CONCLUSIONS}

Based on the results of the evaluation of the implementation of the social care program in spraying disinfectants to prevent the corona virus the Regional Representative Council (DPD) Partai Amanat Nasional (PAN) of Batu City, it can be concluded that the program is run by the Regional Representative Council (DPD) Partai Amanat Nasional (PAN) of Batu City in the form of a social care program for spraying disinfectants to reduce the spread of the corona virus through inanimate objects in the Batu City area can almost be said to be successful because their initial goal of carrying out this program for Islamic boarding schools and foundations in the Batu City area, when residents When they heard the Regional Representative Council (DPD) Partai Amanat Nasional (PAN) of Batu City, the enthusiasm of the people immediately appeared to ask for spraying in their village so that the Regional Representative Council (DPD) Partai Amanat Nasional (PAN) of Batu City experienced problems in volunteer workers.

\section{REFERENCES}

Anon. 2016. "Stakeholder Pemerintah Sebagai Prime Mover Keberhasilan Jejaring Pelayanan Kesehatan Peduli Remaja." Stakeholder Pemerintah Sebagai Prime Mover Keberhasilan Jejaring Pelayanan Kesehatan Peduli Remaja.

Arikunto, Suharsimi. 2006. Prosedur Penelitian Suatu Pendekatan Praktik. Jakarta: Bumi Aksara.

Dahler-Larsen, Peter. The Evaluation Society. Stanford, CA: Stanford University Press, 2012.

Donna M. Metens, Amy T. Wilson. Program Evaluation Theory and Practice. New York, London : The Guilford Press, 2019.

E.N. Kathryn, P.H. Harry, S.W. Joseph. Handbook Practical Program Evaluation. New Jersey : Jossey Bass, 2015.

Jody L. Fitzpatrick, James R. Sanders, Blaine R. Worthen. Program Evaluation Alternative Approaches and Practical Guidelines. New Jersey : PEARSON, 2011. 
Kadek Alit Arsani, Ni Luh. 2013. "Peranan Program Pkpr (Pelayanan Kesehatan Peduli Remaja) Terhadap Kesehatan Reproduksi Remaja Di Kecamatan Buleleng." Jurnal Ilmu Sosial Dan Humaniora.

Komala, Puti Sri. 2014. "Inaktivasi Bakteri Escherichia Coli Air Sumur Menggunakan Disinfektan Kaporit.” Jurnal Dampak.

Moleong, Lexy J. 2007. Metodologi Penelitian Kualitatif. Bandung : Remaja Rosdakarya.

Mutakallim. 2016. "Pengawasan, Evaluasi Dan Umpan Balik Stratejik." Volume V, Nomor 2.

Patton, Michael Quinn. Qualitative Research and Evaluation Methods. London: SAGE Publications, Inc, 2002.

Rahmawati, Evi and Bagus Kisworo. 2017. "Peran Pendamping Dalam Pemberdayaan Masyarakat Miskin Melalui Program Keluarga Harapan.” Journal of Nonformal Education and Community Empowerment.

Rinaldy, Reza, Soni Akhmad Nulhaqim, And Arie Surya Gutama. 2017. "Proses Community Development Pada Program Kampung Iklim Di Desa Cupang Kecamatan Gempol Kabupaten Cirebon (Studi Kasus Program Bank Sampah Dalam Program Kampung Iklim).” Prosiding Penelitian Dan Pengabdian Kepada Masyarakat.

Setiawan, Didik, James Sibarani, and Iryanti Suprihatin. 2013. "Perbandingan Efektifitas Disinfektan Kaporit, Hidrogen Peroksida, Dan Pereaksi Fenton (H2O2/FE2+)." Cakra Kimia.

Sugiyono. 2007. Metode Penelitian Kuantitatif Koalitatif dan R \& D. Bandung: Elfabeta.

Syaribulan, Syaribulan and Muhammad Akhir. 2017. "Gerakan Sosial Masyarakat Peduli Lingkungan.” Equilibrium: Jurnal Pendidikan.

https://www.facebook.com/pan.kotabatu.1 (Diakses pada tanggal 29 Mei 2020, jam 18:37) 